\title{
Endovascular balloon angioplasty for infrainguinal arterial occlusive disease: Efficacy analysis
}

\author{
Infrainguinal arteriyel tıkayıcı hastalıkta endovasküler balon anjiyoplasti: Etkinlik analizi
}

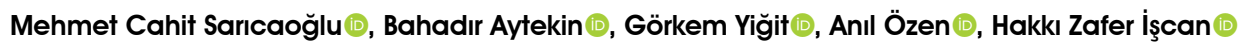

Department of Cardiovascular Surgery, Ankara City Hospital, Ankara, Turkey

\begin{abstract}
Background: We present early and mid-term clinical outcomes of endovascular revascularization for femoropopliteal involvement of peripheral arterial disease.

Methods: A total of 128 patients (113 males, 15 females; mean age: $63.4 \pm 9.9$ years; range, 32 to 87 years) who underwent percutaneous transluminal angioplasty for femoropopliteal lesions between August 2016 and April 2018 were analyzed retrospectively. Treatment with Luminor ${ }^{\circledR}$ paclitaxel-coated drug-eluting balloon catheter or bailout therapy with iVolution ${ }^{\circledR}$ self-expanding nitinol stent were performed. Overall patency rates and freedom from reintervention rates were analyzed using the Kaplan-Meier analysis. The primary patency and freedom from reintervention to target lesion rates at 12 and 24 months were evaluated.
\end{abstract}

Results: Technical success was achieved in 133 (93\%) of the interventions with a median follow-up of 11 (range, 1 to 35) months. At 12 and 24 months, the mean overall patency rates were $85.6 \pm 3.7 \%$ and $66.8 \pm 6.7 \%$, respectively and the mean freedom from reintervention to target lesion rates were $91.6 \pm 2.9 \%$ and $78.1 \pm 6.3 \%$, respectively. The primary patency and freedom from reintervention to target lesion rates were significantly higher in the bailout stenting group than the drug-eluting balloon group at 12 months $(97.3 \pm 2.7 \%$ vs. $94.8 \pm 6.1 \%$, respectively, $\mathrm{p}=0.025$ and $97.1 \pm 2.9 \%$ vs. $84.2 \pm 5.5 \%$, respectively, $\mathrm{p}=0.005)$ and at 24 months $(76.9 \pm 7.9 \%$ vs. $55.8 \pm 13.4 \%$, respectively, $\mathrm{p}=0.025$ and $85.2 \pm 7.0 \%$ vs. $70.2 \pm 13.6 \%$, respectively, $\mathrm{p}=0.005)$.

Conclusion: Endovascular procedures including drug-eluting balloon and bailout stenting seem to be effective alternative treatment modalities for treatment of infrainguinal peripheral arterial disease and can be also used in patients with long lesions and/or total occlusion of femoropopliteal arteries.

Keywords: Bail-out therapy, drug-eluting balloon, endovascular procedure, percutaneous transluminal angioplasty, peripheral arterial disease.
$\ddot{O} Z$

Amaç: Bu çalışmada, periferik arter hastalığının femoropopliteal tutulumunda endovasküler revaskülarizasyonun erken ve orta dönem klinik sonuçları sunuldu.

Çalışma planı: Ağustos 2016 - Nisan 2018 tarihleri arasında femoropopliteal lezyonlar nedeniyle perkütan transluminal anjiyoplasti yapılan toplam 128 hasta (113 erkek, 15 kadın; ort. yaş: $63.4 \pm 9.9$ yıl; dağılım, 32-87 yıl) retrospektif olarak incelendi. Luminor $^{\circledR}$ paklitaksel kaplı ilaç salınımlı balon kateteri veya iVolution $^{\circledR}$ kendiliğinden açılan nitinol stent ile kurtarıcı tedavi yapıldı. Genel açıklık oranları ve tekrar girişim olmaması oranları, Kaplan-Meier analizi kullanılarak analiz edildi. On iki ve 24 . ayda primer açıklık ve hedef lezyona tekrar girişim olmaması oranları da değerlendirildi.

Bulgular: Medyan takip süresi 11 (dağılım, 1-35) ay olup, girişimlerin 133'ünde (\%93) teknik başarı sağlandı. On iki ve 24. aylarda ortalama genel açıklık oranları sırasıyla $\% 85.6 \pm 3.7$ ve $\% 66.8 \pm 6.7$ ve ortalama hedef lezyona tekrar girişim olmaması oranları sırasıyla \%91.6 \pm 2.9 ve $\% 78.1 \pm 6.3$ idi. Primer açıklık ve hedef lezyona tekrar girişim olmaması oranları, kurtarıcı stent tedavisi grubunda, ilaç salınımlı balon grubuna kıyasla, 12. ayda (sirasiyla, \%97.3 \pm 2.7 'e kiyasla $\% 94.8 \pm 6.1, \mathrm{p}=0.025$ ve sirasiyla, \%97.1 \pm 2.9 'a kiyasla $\% 84.2 \pm 5.5, \mathrm{p}=0.005$ ) ve 24 . ayda (sirasiyla $\% 76.9 \pm 7.9$ 'a kiyasla $\% 55.8 \pm 13.4, \mathrm{p}=0.025$ ve $\% 85.2 \pm 7.0$ 'ye kıyasla $\% 70.2 \pm 13.6, \mathrm{p}=0.005$ ) anlamlı olarak daha yüksek idi.

Sonuç: İlaç salınımlı balon ve kurtarıcı stentleme dahil olmak üzere endovasküler girişimler, infrainguinal periferik arter hastalığında etkili tedavi seçenekleri olarak görünmekte ve femoropopliteal arterlerin uzun lezyonları ve/veya tam tıkanıklığı olan hastalarda da uygulanabilmektedir.

Anahtar sözcükler: Kurtarıcı tedavi, ilaç salımlı balon, endovasküler işlem, perkütan transluminal anjiyoplasti, periferik arter hastalığı.

Received: August 11, 2019 Accepted: September 16, 2020 Published online: January 13, 2021

Correspondence: Mehmet Cahit Sarıcaoğlu, MD. Ankara Şehir Hastanesi Kalp ve Damar Cerrahisi Kliniği, 06800 Çankaya, Ankara, Türkiye. Tel: +90 535 - 8626690 e-mail: cahitsarica@gmail.com 
Atherosclerotic peripheral arterial disease, which affects about 50 million individuals in the Unites States and Europe, is a major challenging issue that can lead to disabling ischemia, limb loss, and impaired quality of life. ${ }^{[1]}$ Novel interventional modalities such as percutaneous transluminal angioplasty (PTA) with a drug-eluting balloon (DEB) or plain balloon, stent implantation, and atherectomy procedures have dramatically altered the treatment paradigms, particularly for extensive femoropopliteal (FP) lesions. Endovascular strategies have become a well-recognized therapeutic alternative to bypass surgery with the aforementioned technical advancements. ${ }^{[2]}$

The incidence of restenosis of FP lesions following PTA is significant and cannot be ignored, particularly for complex lesions. ${ }^{[3,4]}$ However, paclitaxel-coated balloons have been shown to be superior, compared to plain balloons, in preventing restenosis. ${ }^{[5-8]}$ Furthermore, durability of endovascular interventions have been reported to be improved using self-expanding nitinol stents. ${ }^{[9]}$

While the endeavor for effective and durable therapeutic strategies continues, in this study, we aimed to analyze the early and mid-term clinical outcomes of endovascular revascularization for $\mathrm{FP}$ involvement of peripheral arterial disease performed by cardiovascular surgeons.

\section{PATIENTS AND METHODS}

A total of 128 patients (113 males, 15 females; mean age: $63.4 \pm 9.9$ years; range, 32 to 87 years) who underwent PTA for FP lesions between August 2016 and April 2018 were analyzed retrospectively and assigned prospectively. All patients underwent PTA with the Luminor ${ }^{\circledR}$ paclitaxel-coated DEB catheter (iVascular, S.L.U., Barcelona, Spain) or bailout therapy with iVolution ${ }^{\circledast}$ self-expanding nitinol stent (iVascular, S.L.U., Barcelona, Spain). The patients whose data could have not been reached and who have not agreed to participate in this study were excluded. A written informed consent was obtained from each patient. The study protocol was approved by the Türkiye Yüksek İhtisas Training and Research Hospital Ethics Committee (No: 29620911-929, Date: 31.01.2016). The study was conducted in accordance with the principles of the Declaration of Helsinki. Demographic and clinical data including age, sex, hypertension, dyslipidemia, chronic obstructive pulmonary disease, the presence of coronary artery disease, chronic kidney disease, coronary artery bypass grafting, cigarette smoking, and previous percutaneous interventions were recorded. Pre- and postoperative ankle-brachial indices (ABIs) and creatinine levels which were measured on Day 3 after the intravenous contrast administration were also noted. The overall patency rates and freedom from reintervention were analyzed using the Kaplan-Meier. The primary patency and freedom from reintervention to target lesion rates at 12 and 24 months were also evaluated.

\section{Operative technique}

Prior to PTA, the ABIs of all patients were evaluated using the Duplex ultrasound and, then, were evaluated with the digital subtraction angiography. The PTA was performed under local anesthesia with monitorization by cardiovascular surgeons in the hybrid operating theatre. After placement of a 7-Fr single lumen introducer sheath ipsilaterally or contralaterally to the lesion according to level of the FP lesion, intravenous heparin was administered with an activated clotting time of 180 to $200 \mathrm{sec}$. None of the lesions were predilated. All lesions were dilated with DEB (vessel/balloon ratio of 1:1 on the basis of visual estimate) for a total inflation time of $3 \mathrm{~min}$ at 6 to 14 atmosphere pressure. Balloons were inflated only once. However, when control angiography revealed a residual lesion $(>50 \%$ stenosis), flow-limiting dissection or atherosclerotic plaque deformation, a second DEB was carried out and dilatation was maintained for a longer period ( $\geq 3 \mathrm{~min}$ ). In these cases in which residual stenosis or flow-limiting dissection persisted following repeated dilatation, self-expanding nitinol stents were implanted as bailout therapy.

\section{Statistical analysis}

Statistical analysis was performed using the SPSS version 16.0 (SPSS Inc., Chicago, IL, USA). Distribution of continuous variables were tested using the Shapiro-Wilk test. Descriptive data were presented in mean \pm standard deviation (SD) or median (min-max) for continuous variables and in number and percentage for nominal variables. Dependent in-group variables were compared using the Wilcoxon test. A $p$ value of $<0.05$ was considered statistically significant.

\section{RESULTS}

There were $143 \mathrm{FP}$ lesions in a total of 128 patients included in the study. The incidence of hypertension and diabetes was $59.4 \%$ and $55.5 \%$, respectively. Most of the patients $(63.3 \%)$ presented with moderate claudication (Rutherford Class 3), ${ }^{[2]}$ and proximal superficial femoral artery (SFA) was the most 
Table 1. Baseline demographic and clinical data of patients

\begin{tabular}{lcccc}
\hline & $\mathrm{n}$ & $\%$ & Mean \pm SD & Min-Max \\
\hline Age (year) & & & $63.4 \pm 9.9$ & $32-87$ \\
Sex & 113 & 88.3 & & \\
$\quad$ Male & 76 & 59.4 & \\
Hypertension & 56 & 43.8 & \\
Coronary artery disease & 25 & 19.5 & \\
Chronic obstructive lung disease & 18 & 14.1 & \\
Coronary artery bypass grafting & 70 & 54.7 & \\
Hyperlipidemia & 71 & 55.5 & \\
Diabetes mellitus & 11 & 8.6 & \\
Chronic renal failure & 29 & 22.7 & \\
Previous intervention for peripheral & & & \\
artery disease & 96 & 75 & \\
Current smoking & 10 & 7.8 & \\
Wound & & & $50.5 \pm 8.6$ \\
Left ventricular ejection fraction $(\%)$ & & & \\
Rutherford Class & 0 & 0 & \\
0 & 0 & 0 & \\
1 & 25 & 17.5 & \\
2 & 91 & 63.6 & \\
3 & 0 & 15.4 & \\
4 & 3.5 & \\
6 & 0 & 0 & \\
\hline
\end{tabular}

SD: Standard deviation; Min: Minimum; Max: Maximum.

common lesion site in $82.5 \%$ of the patients. Baseline demographic and clinical characteristics of the patients are shown in Table 1 and lesion features are presented in Table 2.

The median follow-up was 11 (range, 1 to 34 ) months. During follow-up, no mortality was seen and none of the patients withdrew his/her consent or lost to follow-up.

Angioplasty was successful in 133 (93\%) of the interventions. Bailout stenting was required in 51 (35.7\%) of lesions and only nine $(6.3 \%)$ of the lesions needed percutaneous reintervention. However, eight lesions (5.6\%) needed FP bypass during the follow-up. The mean ABIs significantly improved in the postprocedural period, compared to pre-procedural measurements $(0.78 \pm 0.19$ vs. $0.40 \pm 0.11$, respectively) $(\mathrm{p}<0.001)$ (Table 3). Clopidogrel was prescribed to all patients, whereas cilostazol was only prescribed for patients with poor distal vasculature (Table 4).

In one patient, an isolated perforation developed at the target lesion site and resolved spontaneously.
Table 2. Lesion characteristics $(n=143)$

\begin{tabular}{lcc}
\hline & $\mathrm{n}$ & $\%$ \\
\hline TASC classification & & \\
A & 55 & 38.5 \\
B & 57 & 39.9 \\
C & 25 & 17.5 \\
D & 6 & 4.1 \\
Lesion localizations & & \\
Common femoral artery & 7 & 4.9 \\
Superficial femoral artery proximal & 118 & 82.5 \\
Superficial femoral artery distal & 56 & 39.2 \\
Popliteal artery & 20 & 14 \\
Lesion length & & \\
0 & 5 & 3.5 \\
1 & 47 & 32.9 \\
2 & 30 & 21 \\
3 & 41 & 28.6 \\
4 & 15 & 10.5 \\
5 & 5 & 3.5 \\
Infrapopliteal lesion & 75 & 52.4 \\
\hline TASC: Trans-Atlantic Inter-Society Consensus Document; $0: 1 \leq 5 \mathrm{~cm}, 1: 5<1 \leq 10 \mathrm{~cm}$, \\
$2: 10<1 \leq 15 \mathrm{~cm}, 3: 15<1 \leq 20 \mathrm{~cm}, 4: 20<1 \leq 25 \mathrm{~cm}, 5: 1>25 \mathrm{~cm}$. & &
\end{tabular}


Table 3. Peri-procedural data

\begin{tabular}{lcccc}
\hline & $\mathrm{n}$ & $\%$ & Mean \pm SD & Min-Max \\
\hline Drug-eluting balloon* & 132 & 92.3 & & \\
Stenting & 51 & 35.7 & & \\
Technical success & 133 & 93.0 & & \\
Complication & 3 & 2.1 & & \\
Pseudoaneurysm & 2 & 1.4 & & \\
Rupture & 1 & 0.7 & & \\
Pre-procedural ABI** & & & $0.4 \pm 0.1$ & $0.12-0.7$ \\
Post-procedural ABI & & & $0.8 \pm 0.2$ & $0.12-1.65$ \\
Pre-procedural creatinine level & & & $1.2 \pm 0.9$ & $0.51-7.2$ \\
Post-procedural creatinine level & & & $1.2 \pm 1.1$ & $0.51-9.36$ \\
\hline
\end{tabular}

SD: Standard deviation; Min: Minimum; Max: Maximum; ABI: Ankle-brachial indices; * Paclitaxel coated-drug eluting balloon angioplasty; ** Ankle-Brachial Index.

Table 4. Post-procedural data

\begin{tabular}{lccccc}
\hline & $\mathrm{n}$ & $\%$ & Mean \pm SD & Median & Min-Max \\
\hline Clopidogrel medication & 143 & 100 & & & \\
Cilostazol medication & 50 & 35 & & & \\
Statin medication & 94 & 66.2 & & & \\
Hospitalization period (day) & & & $1.8 \pm 1.6$ & & $1-11$ \\
Claudication at control (Rutherford Class $\geq 2)$ & 26 & 18.2 & & & \\
Follow-up period (month) & & & $13.2 \pm 8.7$ & 11 & $1-34$ \\
Freedom from >50\% restenosis & 114 & 79.7 & & & \\
Decision after control examination & & & & & \\
$\quad$ Medical follow-up & 126 & 88.1 & & & \\
$\quad$ Surgical intervention & 8 & 5.6 & & & \\
$\quad$ Percutaneous intervention & 9 & 6.3 & & & \\
\hline
\end{tabular}

SD: Standard deviation; Min: Minimum; Max: Maximum.

Table 5. Clinical outcomes at Months 12 and 24

\begin{tabular}{|c|c|c|c|c|c|}
\hline & \multicolumn{2}{|c|}{ Bail-out stenting } & \multicolumn{2}{|c|}{ No bail-out stenting } & \multirow[b]{2}{*}{$p$} \\
\hline & $\mathrm{n}$ & Mean \pm SE & $\mathrm{n}$ & Mean \pm SE & \\
\hline \multicolumn{6}{|l|}{ Primary patency } \\
\hline 12 month & 50 & $97.3 \pm 2.7$ & 87 & $94.8 \pm 6.1$ & 0.025 \\
\hline 24 month & 39 & $76.9 \pm 7.9$ & 51 & $55.8 \pm 13.4$ & 0.005 \\
\hline Freedom from reintervention to $\mathrm{TL}$ & & & & & 0.025 \\
\hline 12 month & 49 & $97.1 \pm 2.9$ & 77 & $84.2 \pm 5.5$ & 0.005 \\
\hline 24 month & 43 & $85.2 \pm 7.0$ & 65 & $70.2 \pm 13.6$ & \\
\hline
\end{tabular}

SE: Standard error; TL: Target lesion.

Two patients developed a pseudoaneurysm following the removal of the introducer sheath and these pseudoaneurysms were repaired surgically. There was a marked increase in creatinine levels post-procedurally $(\mathrm{p}=0.033)$ (Table 3).
According to the Kaplan-Meier estimates of 12 and 24 months of follow-up, the mean overall patency rates were $85.6 \pm 3.7 \%$ and $66.8 \pm 6.7 \%$, respectively and the mean freedom from reintervention to target lesion rates were $91.6 \pm 2.9 \%$ and $78.1 \pm 6.3 \%$, respectively (Figures 1 and 2). 


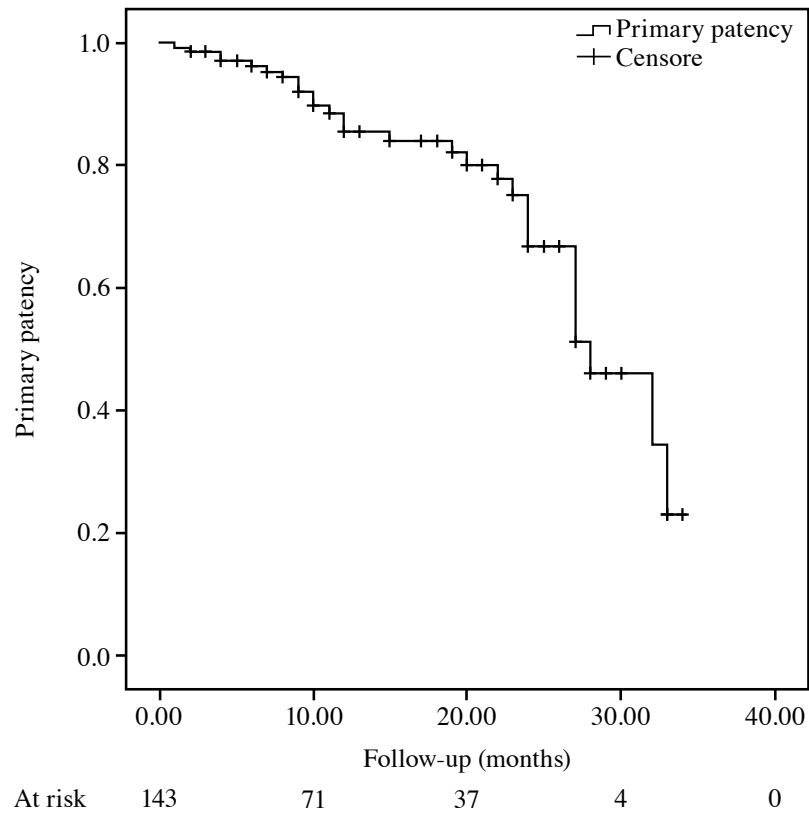

Figure 1. Primary patency rates of all cohort.

Furthermore, the primary patency and freedom from reintervention to target lesion rates were significantly higher in bailout stenting group, compared to PTA with only DEB group at 12 months $(97.3 \pm 2.7 \%$ vs. $94.8 \pm 6.1 \%$, respectively; $\mathrm{p}=0.025$ and $97.1 \pm 2.9 \%$ vs. $84.2 \pm 5.5 \%$, respectively, $\mathrm{p}=0.005)$ and at 24 months $(76.9 \pm 7.9 \%$ vs. $55.8 \pm 13.4 \%$, respectively, $\mathrm{p}=0.025$ and $85.2 \pm 7.0 \%$ vs. $70.2 \pm 13.6 \%$, respectively, $\mathrm{p}=0.005$ ) (Table 5). The restenosis rates in FP lesions greater than 15 $\mathrm{cm}$ were $20 \%$ with bare metal stents (BMSs) and $30 \%$ with DEBs.

Although all patients had claudication preprocedurally, a total of $81.8 \%$ of them had mild symptoms or became asymptomatic at the end of the follow-up $(\mathrm{p}<0.001)$.

\section{DISCUSSION}

In recent years, the treatment of chronic lower extremity ischemia has shifted toward endovascular approach in many centers. ${ }^{[10]}$ In our cardiovascular clinic, the application of percutaneous revascularization procedures has developed over the past five years and all of them have been achieved by cardiovascular surgeons, enabling immediate treatment of intraoperative and acute postoperative complications or failed percutaneous procedures. Hence, these advantages have led us to study the efficacy of the use of DEBs and BMSs.

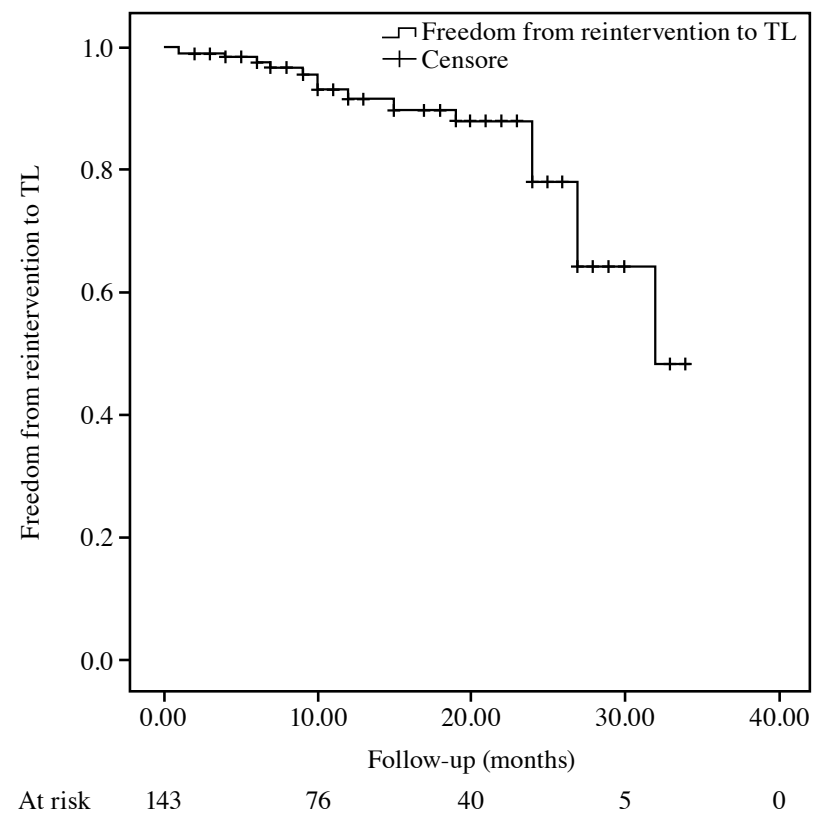

Figure 2. Freedom from reintervention to target lesion rates of all cohort.

TL: Target lesion.

The last report of Trans-Atlantic Inter-Society Consensus (TASC) has offered the endovascular therapy as treatment of choice for infrainguinal lesions and even for more complex stenosis or occlusions (TASC-C lesions). ${ }^{[1]}$ At the present day, even chronic total occlusions can be cured successfully using endovascular treatment. ${ }^{[12]}$ The current guidelines strongly recommend the use of DEBs among the therapeutic options for FP diseases, particularly for high risk patients. ${ }^{[13,14]}$ In addition, DEBs have been suggested to be cost-effective and safe, particularly in the short term, for the treatment of the FP lesions by large randomized-controlled trials including Global Clinical Study for the Treatment of Comprehensive Superficial Femoral and/or Popliteal Artery Lesions Using the IN.PACT Admiral ${ }^{\mathrm{TM}}$ Drug-Eluting Balloon (IN.PACT) and Pilot Study for the Treatment of Subjects With Symptomatic Femoropopliteal Artery Disease (COMPARE) studies. ${ }^{[15-18]}$

According to our study results, the early outcomes of PTA are favorable and mid-term results are acceptable and in agreement with previous studies. The Effectiveness of Paclitaxel-coated Luminor ${ }^{\circledR}$ Balloon Catheter Versus Uncoated Balloon Catheter in the Arteria Femoralis Superficialis (EffPAC) study similarly reported that Luminor $^{\circledR}$ DEB (iVascular, S.L.U., Barcelona, Spain) demonstrated 90.3\% primary patency rate and $98.7 \%$ freedom from 
reintervention at 12 months and $90.2 \%$ and $97.2 \%$ at 24 months, respectively. ${ }^{[19,20]}$ Werk et al. ${ }^{[21]}$ and Schroë et al. ${ }^{[22]}$ reported a short-term primary patency rate of $94.3 \%$ and $81 \%$, respectively. ${ }^{[21,22]}$ Another multi-center, large-scale, prospective study showed a patency rate of $65.2 \%$ at 12 months.$^{[8]}$ Similarly, Tepe et al. ${ }^{[6]}$ found a primary patency rate in 154 patients of $85 \%$ at 24 months.

Complex FP lesions are challenging issues for PTA procedures. A two-year, multi-center, prospective study of long FP lesions revealed a primary patency rate of $70.4 \%$ and a restenosis rate of up to $50 \%$, following stenting of long superficial femoral artery lesions. ${ }^{[23]}$ A recent clinical trial underlined the longterm restenosis rates in challenging FP lesions: $17 \%$ with drug-eluting stents and $20 \%$ with DEBs. ${ }^{[24]}$ Similarly, we detected restenosis rates in FP lesions of greater than $15 \mathrm{~cm}$ as $20 \%$ with BMSs and $30 \%$ with DEBs. At 24 months, the overall freedom from reintervention to target lesion rates were significantly higher in the bailout stenting group, compared to PTA with only DEB, $(85.2 \%$ vs. $70.2 \%$, respectively; $p=0.005)$. In the Efficacy of the SelfExpanding iVolution ${ }^{\circledR}$ nitinol stent for treatment of femoropopliteal lesions (EVOLUTION) study reported that iVolution $^{\circledR}$ self-expanding nitinol stent (iVascular, S.L.U., Barcelona, Spain) had showed $86.3 \%$ primary patency rate and $88.0 \%$ freedom from revascularization at 12 months and $76.7 \%$ and $77.2 \%$ at 24 months, respectively. ${ }^{[25,26]}$ However, Deloose ${ }^{[27,28]}$ reported that, in the Clinical Trial Investigating the Combination Therapy With Luminor ${ }^{\circledR}$ DCB and iVolution Stent in TASC C and D Femoropopliteal Lesions (TINTIN), a primary patency of $96.5 \%$ and freedom from revascularization rate of $98.9 \%$ at six months and these figures were $90.5 \%$ and $94.4 \%$ at 12 months, respectively.

Consistent with Black et al., ${ }^{[10]}$ we concluded that PTA procedures did not preclude secondary surgical revascularization to salvage the limb. In their series, five of 95 patients $(5.3 \%)$ underwent surgical bypass. In our report, eight patients $(6.3 \%)$ underwent successful FP bypass at the end of the follow-up. In the aforementioned study, one patient $(1.1 \%)$ developed a femoral hematoma after sheath removal and required open surgical repair of a femoral pseudoaneurysm, ${ }^{[15]}$ while two patients $(1.4 \%)$ underwent surgical repair for the same reason in our study. Also, we found an isolated perforation in one patient $(0.7 \%)$ at the target lesion site and it was resolved spontaneously as in the aforementioned study reporting one patient $(1.1 \%)$ with an arterial rupture. ${ }^{[15]}$
Improvement in the $\mathrm{ABI}$ is essential following treatment of peripheral arterial disease. Similar to the findings of Pastromas et al. ${ }^{[29]}$ and Iida et al., ${ }^{[30]}$ there was a significant improvement in the ABIs and Rutherford classes in all lesions, including the complex ones $(\mathrm{p}<0.001)$ at 12 months. In our study, $81.8 \%$ of the patients had mild symptoms of claudication, or became asymptomatic at the end of the follow-up period.

Although many randomized-controlled studies have shown that the use of DEB and BMS is suitable in the treatment of long (greater than $15 \mathrm{~cm}$ ), complex FP lesions; long-term follow-up with large-scale, prospective, comparative, randomized, protocol-driven device trials would provide more useful outcomes in determining the safety and durability of treatment in the future. ${ }^{[31]}$

With the advances in PTA technology, surgical experience for endovascular interventions of cardiovascular surgeons have developed rapidly. ${ }^{[32,33]}$ The surgeons should be able to offer patients advice on both percutaneous and surgical approaches used in the treatment of peripheral arterial disease, thus providing the patient with a variety of options catered to their needs. The results of the present study show that endovascular procedures can be performed by cardiovascular surgeons with high success and low complication rates. Cardiovascular surgeons should be encouraged to involve even more in this field, since they possess the understanding of the cardiovascular system and experience in the surgical treatment of arterial disease requiring practice of PTA and in combating pre-, intra-, and post-procedural complications.

Nonetheless, our study has several limitations. Firstly, the numerical stenosis diameter was unable to be established in this study and, therefore, it could not be compared to the findings of other studies. Secondly, the calcification load of the arteries and the reference vessel diameters could not be determined. The guidewire was advanced easily across the lesions in all, including the total occlusions, probably due to the low calcium load; however, we should also consider that there may be thrombosis. Therefore, vessel preparation using plain balloon or atherectomy was not performed, which may be also a limitation to the study. Moreover, the inclusion of patients who previously underwent percutaneous interventions can be deemed as a limitation; however, statistical analysis revealed that there was no significant difference in the primary patency rates at 12 and 24 months between the redo cases and the others $(91.1 \pm 6.3$ vs. $76.9 \pm 10.7$ and $81.8 \pm 4.8$ vs. $63.7 \pm 8.3$ respectively, $\mathrm{p}=0.488$ ). 
Finally, a quality of life survey was unable to be used for the evaluation of quality of life of the patients.

In conclusion, endovascular procedures including drug-eluting balloon and bailout stenting seem to be effective alternative treatment modalities for the treatment of infrainguinal peripheral arterial disease, and also can be used in patients with long lesions and/or total occlusion of femoropopliteal arteries. However, long-term follow-up with a large-scale, prospective, comparative, randomized device trials would be more useful in determining the safety and durability of treatment and its effects on quality of life.

\section{Declaration of conflicting interests}

The authors declared no conflicts of interest with respect to the authorship and/or publication of this article.

\section{Funding}

The authors received no financial support for the research and/or authorship of this article.

\section{REFERENCES}

1. 2014 'IN.PACT Admiral' Drug-Coated Balloon From Medtronic Outperforms Standard Angioplasty In Landmark Study. Medtronic. News and Information. Available at: http:// newsroom.medtronic.com/phoenix.zhtml?c=251324\&p=irolnewsArticle \&ID=1916027

2. Shammas NW, Abi Doumet A, Karia R, Khalafallah R. An overview of the treatment of symptomatic common femoral artery lesions with a focus on endovascular therapy. Vasc Health Risk Manag 2020;16:67-73.

3. Rocha-Singh KJ, Jaff MR, Crabtree TR, Bloch DA, Ansel G; VIVA Physicians, Inc. Performance goals and endpoint assessments for clinical trials of femoropopliteal bare nitinol stents in patients with symptomatic peripheral arterial disease. Catheter Cardiovasc Interv 2007;69:910-9.

4. Davies MG, Anaya-Ayala JE. Endovascular techniques in limb salvage: cutting, cryo, brachy, and drug-eluting balloons. Methodist Debakey Cardiovasc J 2013;9:69-72.

5. Werk M, Langner S, Reinkensmeier B, Boettcher HF, Tepe $\mathrm{G}$, Dietz U, et al. Inhibition of restenosis in femoropopliteal arteries: paclitaxel-coated versus uncoated balloon: femoral paclitaxel randomized pilot trial. Circulation 2008;118:1358-65.

6. Tepe G, Zeller T, Albrecht T, Heller S, Schwarzwälder $\mathrm{U}$, Beregi JP, et al. Local delivery of paclitaxel to inhibit restenosis during angioplasty of the leg. $\mathrm{N}$ Engl $\mathrm{J}$ Med 2008;358:689-99.

7. Micari A, Cioppa A, Vadalà G, Stabile E, Castriota F, Pantaleo $\mathrm{P}$, et al. A new paclitaxel-eluting balloon for angioplasty of femoropopliteal obstructions: acute and midterm results. EuroIntervention 2011;7 Suppl K:K77-82.

8. Rosenfield K, Jaff MR, White CJ, Rocha-Singh K, MenaHurtado C, Metzger DC, et al. Trial of a paclitaxel-coated balloon for femoropopliteal artery disease. N Engl J Med 2015;373:145-53.

9. Laird JR, Schneider PA, Tepe G, Brodmann M, Zeller T, Metzger C, et al. Durability of treatment effect using a drugcoated balloon for femoropopliteal lesions: 24-month results of IN.PACT SFA. J Am Coll Cardiol 2015;66:2329-38.

10. Black JH 3rd, LaMuraglia GM, Kwolek CJ, Brewster DC, Watkins MT, Cambria RP. Contemporary results of angioplasty-based infrainguinal percutaneous interventions. J Vasc Surg 2005;42:932-9.

11. Norgren L, Hiatt WR, Dormandy JA, Nehler MR, Harris KA, Fowkes FG; TASC II Working group. Inter-society consensus for the management of peripheral arterial disease (TASC II). J Vasc Surg 2007;45 Suppl S:S5-67.

12. Yiğit G, Sarıcaoğlu MC, Çetinkaya F, Özen A, İşcan HZ. Endovascular treatment of chronic total occlusion of iliac/ femoral arteries: Mid-term follow-up. Turk J Vasc Surg 2020;29:7-12.

13. Feldman DN, Armstrong EJ, Aronow HD, Gigliotti OS, Jaff MR, Klein AJ, et al. SCAI consensus guidelines for device selection in femoral-popliteal arterial interventions. Catheter Cardiovasc Interv 2018;92:124-40.

14. Conte MS, Bradbury AW, Kolh P, White JV, Dick F, Fitridge $\mathrm{R}$, et al. Global vascular guidelines on the management of chronic limb-threatening ischemia. Eur J Vasc Endovasc Surg 2019;58:S1-S109.e33.

15. Katsanos K, Geisler BP, Garner AM, Zayed H, Cleveland T, Pietzsch JB. Economic analysis of endovascular drug-eluting treatments for femoropopliteal artery disease in the UK. BMJ Open 2016;6:e011245.

16. Salisbury AC, Li H, Vilain KR, Jaff MR, Schneider PA, Laird JR, et al. Cost-effectiveness of endovascular femoropopliteal intervention using drug-coated balloons versus standard percutaneous transluminal angioplasty: Results from the IN.PACT SFA II Trial. JACC Cardiovasc Interv 2016;9:2343-52.

17. Sridharan ND, Boitet A, Smith K, Noorbakhsh K, Avgerinos $\mathrm{E}$, Eslami $\mathrm{MH}$, et al. Cost-effectiveness analysis of drugcoated therapies in the superficial femoral artery. J Vasc Surg 2018;67:343-52.

18. Steiner S, Schmidt A, Zeller T, Tepe G, Thieme M, Maiwald L, et al. COMPARE: prospective, randomized, non-inferiority trial of high- vs. low-dose paclitaxel drug-coated balloons for femoropopliteal interventions. Eur Heart J 2020;41:2541-52.

19. Teichgräber U,Lehmann T, Aschenbach R, Scheinert D, Zeller $\mathrm{T}$, Brechtel K, et al. Efficacy and safety of a novel paclitaxelnano-coated balloon for femoropopliteal angioplasty: one-year results of the EffPac trial. EuroIntervention 2020;15:e1633-e1640.

20. Teichgräber U, Lehmann T, Aschenbach R, Scheinert D, Zeller T, Brechtel K, et al. Drug-coated balloon angioplasty of femoropopliteal lesions maintained superior efficacy over conventional balloon: 2-year results of the randomized effpac trial. Radiology 2020;295:478-87.

21. Werk M, Albrecht T, Meyer DR, Ahmed MN, Behne A, Dietz $\mathrm{U}$, et al. Paclitaxel-coated balloons reduce restenosis after femoro-popliteal angioplasty: Evidence from the randomized PACIFIER trial. Circ Cardiovasc Interv 2012;5:831-40. 
22. Schroë H, Holden AH, Goueffic Y, Jansen SJ, Peeters P, Keirse K, et al. Stellarex drug-coated balloon for treatment of femoropopliteal arterial disease-The ILLUMENATE Global Study: 12-Month results from a prospective, multicenter, single-arm study. Catheter Cardiovasc Interv 2018;91:497-504.

23. Micari A, Nerla R, Vadalà G, Castriota F, Grattoni C, Liso A, et al. 2-Year results of paclitaxel-coated balloons for long femoropopliteal artery disease: Evidence from the SFA-long study. JACC Cardiovasc Interv 2017;10:728-34.

24. Gökgöl C, Schumann S, Diehm N, Zheng G, Büchler P. In vivo quantification of the deformations of the femoropopliteal segment: percutaneous transluminal angioplasty vs nitinol stent placement. J Endovasc Ther 2017;24:27-34.

25. Bosiers M, Deloose K, Callaert J, Peeters P, Verbist J, van den Eynde W, et al. EVOLUTION Study: 12-month results. J Cardiovasc Surg (Torino) 2019;60:490-5.

26. Bosiers M. 24-month outcomes in the EVOLUTION study Investigating the iVolution stent in fempop lesions. Presented at the Leipzig Interventional Course; 2019 Jan 22-25; Leipzig, Germany.

27. Deloose K. The Belgian TINTIN trial shows impressive 6-month results in lesions of $24 \mathrm{~cm}$. Presented at the Cardiovascular and Interventional Radiological Society of
Europe Congress; 2019 Sep 7-11; Barcelona, Spain.

28. Deloose K. The 1-year clinical outcomes of TINTIN Trial. Presented at the Leipzig Interventional Course; 2020 Jan 28-31; Leipzig, Germany.

29. Pastromas G, Katsanos K, Krokidis M, Karnabatidis D, Spiliopoulos S. Emerging stent and balloon technologies in the femoropopliteal arteries. ScientificWorldJournal 2014;2014:695402.

30. Iida O, Soga Y, Urasawa K, Saito S, Jaff MR, Wang H, et al. Drug-coated balloon vs standard percutaneous transluminal angioplasty for the treatment of atherosclerotic lesions in the superficial femoral and proximal popliteal arteries: One-year results of the MDT-2113 SFA Japan Randomized Trial. J Endovasc Ther 2018;25:109-17.

31. Krokidis M, Spiliopoulos S, Katsanos K, Sabharwal T. Peripheral applications of drug-coated balloons: past, present and future. Cardiovasc Intervent Radiol 2013;36:281-91.

32. Uğur M, Alp İ, Arslan G, Şenay Ş, Selçuk İ, Selçuk A, et al. Vasküler hastalıkların yönetiminde endovasküler ve hibrid uygulamalar: Kardiyovasküler cerrahi kliniği deneyimleri. Turk Gogus Kalp Dama 2012;20:230-42.

33. Temizkan V, Uçak A, Alp İ, Kardeşoğlu E, Selçuk A, Can $\mathrm{MF}$, et al. Our experiences on endovascular and hybrid treatment of peripheral arterial diseases. Turk Gogus Kalp Dama 2018;26:237-45. 